\title{
Concentrations of proinsulin like molecules predict coronary heart disease risk independently of insulin: prospective data from the Caerphilly Study
}

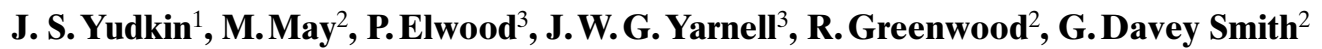 \\ ${ }^{1}$ Department of Medicine, University College London Medical School, London, UK \\ ${ }^{2}$ Department of Social Medicine, University of Bristol, Bristol, UK \\ ${ }^{3}$ MRC Epidemiology Unit, Llandough Hospital, Penarth, South Glamorgan, Wales
}

\begin{abstract}
Aims/hypothesis. Higher concentrations of insulin correlate with several coronary heart disease (CHD) risk factors and have been shown to predict incident CHD in several studies, leading to hypotheses concerning the proatherogenic properties of insulin. However, in cross-sectional studies, relationships of concentrations of the insulin precursor molecules, proinsulin and des 31, 32 proinsulin, relate as strongly, or more strongly, to levels of risk factors and to (prevalent) CHD.

Methods. We investigated the relationship between concentrations of insulin, measured with a specific assay, and of proinsulin-like molecules, and risk factors in 1181 non-diabetic men 50-64 years old during Phase II of the Caerphilly Study. We also related concentrations of these molecules to incident CHD during the 10-14 years follow-up.

Results. The relationship between concentrations of insulin, of proinsulin and of des 31, 32 proinsulin and BMI $(r=0.36-0.45)$, triglyceride $(r=0.25-0.31)$, high density lipoprotein- (HDL-) cholesterol $(r=-0.17$ to -0.21$)$, systolic $(r=0.05-0.11)$ and diastolic blood pressure $(r=0.11-0.15)$ were similarly close, those with risk factors being somewhat and similarly reduced after adjustment for BMI. The correlation between insulin and of proinsulin-like molecules and those plasminogen activator inhibitor-1
\end{abstract}

(PAI-1) antigen was also similar $(r=0.28-0.29)$. There was a negative correlation between concentrations of proinsulin-like molecules - but not insulin and birth weight. Insulin concentrations correlated positively with height $(r=0.12)$. In logistic regression models, concentrations of proinsulin-like molecules, but not insulin, predicted incident of CHD over a follow-up of 10-14 years (insulin - standardised odds ratio (SOR) 1.30 (95\%-CI) 0.91, 1.85), $p=0.15$; des 31 , 32 proinsulin - SOR 1.38 (95\%-CI 1.02, 1.85), $p=0.034$; sum of proinsulin-like molecules - SOR $1.54(95 \%$-CI 1.07, 2.20), $p=0.019$ after adjusting for age and BMI. The predictive ability of these molecules was reduced by around one third after adjustment for standard risk factors and concentrations of tryglyceride and HDL-cholesterol, and by about half after further adjustment for PAI-1 concentrations.

Conclusion/interpretation. We conclude that concentrations of proinsulin-like molecules provide a better way to predict the incidence of CHD than those of insulin. However, the lack of biological evidence for a causative relationship suggests an association through a common antecedent, and this antecedent is not likely to be intrauterine growth retardation. [Diabetologia (2002) 45: 327-336]

Keywords Proinsulin, des 31, 32 proinsulin, insulin, plasminogen activator inhibitor, coronary heart disease.
Received: 22 June 2001 and in revised form: 30 October 2001

Corresponding author: J. S. Yudkin, Department of Medicine, University College London Medical School, Holborn Union Building, Archway Wing, Whittington Hospital, Archway Road, London, N193UA, UK, e-mail: j.yudkin@ucl.ac.uk
Abbreviations: PAI, Plasminogen activator inhibitor; SOR, standardised odds ratio; WHO, World Health Organisation; IQ, inter quartile; UKPDS, United Kingdom Prospective Diabetes Study 
The clustering of hypertension, dyslipidaemia, central obesity and disturbed fibrinolysis has been noted in both diabetic and non-diabetic subjects. Insulin resistance and consequent hyperinsulinaemia have been proposed as the primary abnormality responsible for this association, through mechanisms such as sodium retention, sympathetic nervous system activation, and an excessive supply of non-esterified fatty acids as substrate for hepatic lipogenesis [1-4]. Hyperinsulinaemia could also be proatherogenic in its own right [5], and studies have shown that increased concentrations of insulin, either fasting or after a glucose load, predict incident coronary heart disease (CHD) [6-11].

Until recently, most assays for insulin cross-reacted with the insulin precursor molecules, proinsulin and des 31, 32 proinsulin [12]. In non-diabetic subjects, these molecules together comprise only some $10 \%$ of all insulin-like molecules [13-15], but in patients with Type II (non-insulin-dependent) diabetes mellitus this proportion is higher [13-16]. In diabetic patients, we found that the relationships between several cardiovascular risk factors and insulin, measured using a non-specific assay, could in fact represent relationships with the precursor molecules and not with insulin itself [17]. In the general population, proinsulin-like molecules contribute only around $10 \%$ of the concentrations measured using a non-specific assay, and are unlikely to lead to erroneous conclusions. We have, nevertheless, shown that in subjects with normal glucose tolerance, concentrations of proinsulin and des 31, 32 proinsulin showed relationships with a number of cardiovascular risk factors that were similar to, or stronger than, those of fasting or post-glucose load insulin [18]. Similar findings were reported from a study in Texas [19]. Furthermore, we found a relationship between all three molecules and concentrations of both fibrinogen and low density lipoprotein cholesterol, which are not thought to belong to the insulin-resistance syndrome [18]. More recently, we reported very similar strength in crosssectional relationships between concentrations of each of the molecules and prevalent CHD in a study of 1291 europid and south Asian non-diabetic subjects [20]. Because these molecules comprise only around $10 \%$ of all insulin-like molecules, and the receptor binding and biological action of these molecules is around $1-8 \%$ of that of insulin (14), it is not probable that proinsulin-like molecules are involved in causing the insulin-resistance syndrome or CHD itself (20). Some other factor could provide a common antecedent, such as growth retardation in early life [18], which has been linked to insulin resistance [21, $22]$, to the insulin-resistance syndrome $[23,24]$ and to higher concentrations of proinsulin-like molecules $[23,25]$.

Evidence of antecedence is vital for showing causality in a relationship. For this reason, we studied the relationship between concentrations of insulin and of proinsulin-like molecules and incident CHD in 1181 men 50-64 years of age who had blood samples stored during Phase II of the Caerphilly Study (1984-88). This also provided the opportunity to study the cross-sectional relationships between concentrations of the insulin-like molecules and cardiovascular risk factors, and, in a subset of around $40 \%$ of the cohort, with recalled birth weight. The hypotheses we wished to test were, firstly, that concentrations of intact and of des 31,32 proinsulin correlate with levels of triglyceride, high density lipoprotein (HDL) cholesterol, low density-lipoprotein (LDL) cholesterol, fibrinogen, plasminogen activator inhibitor-1 (PAI-1) and blood pressure in non-diabetic men independently of concentrations of insulin. Secondly, absolute and relative concentrations of proinsulinlike molecules are higher in men who subsequently develop CHD, and thirdly, these associations could be explained through common associations with low birth weight.

\section{Subjects and methods}

Phase I of the Caerphilly Study involved the examination of 2512 men $45-59$ years of age from a defined geographical area. These individuals, representing $89 \%$ of those eligible, were studied between 1979 and 1983 (26). Of these subjects, $2000(79.6 \%)$ were re-examined between 1984 and 1988 in Phase II of the Study, when they were 50-64 years old. Each subject completed a questionnaire documenting employment, parental employment, smoking habits, alcohol consumption, and work and leisure time activity. In addition, subjects completed the WHO Cardiovascular Questionnaire for documentation of angina and intermittent claudication [27]. About $40 \%$ of the subjects provided their birth weight, ascertained from their mother or a close female relative, which have been reported to show strong associations with both anthropometric measures in adulthood (28) and incident CHD (29).

The height of all subjects without shoes and weight wearing light clothing was recorded. BMI was calculated as weight in $\mathrm{kg} /(\text { height in metres })^{2}$. Blood pressure was measured in duplicate with a random zero sphygmomanometer (Hawksley, Lancing, Sussex) after a 10-min rest. The men were asked to return for venesection on another day, usually about 1 week later, after an overnight fast when a blood sample was taken with a $19 \mathrm{G}$ cannula and with minimum stasis for glucose and lipids. Lithium heparin aliquots were frozen at $-70^{\circ} \mathrm{C}$ until assay for insulin and for proinsulin-like molecules in 1995-1996. Another sample, taken into $3.8 \%$ sodium citrate, was frozen at $-70^{\circ} \mathrm{C}$ for assay of PAI-1 activity in 1993-1994.

All subjects studied during Phase II were reinvestigated at Phase III (1989-1993) and Phase IV (1994-98), during both of which phases each subject repeated the WHO Cardiovascular Questionnaire [27] for angina, and a 12 lead electrocardiogram was recorded. The ECGs were Minnesota coded [27] by two independent observers and myocardial infarction was classified as codes 1.1, 1.2 and 7.1. Incident CHD to January 1998 (death) or the date of examination during Phase IV of the Study, or the date last examined (if the subject was lost to follow-up) was used as the dependent variable in logistic regression analyses. Data for mortality were obtained by flagging at 
the National Health Service Central Registry and from local hospitals until 1 January 1998. Because of a very low autopsy rate $(<10 \%)$, CHD deaths were defined as those coded as 410-414 in the International Classification of Diseases (9th Revision, $n=63$ ). All incident CHD events were defined as CHD deaths, together with similarly classified hospital admissions (using Hospital Activity Analysis for these hospitals $(n=52)$ ), and subjects who had developed new myocardial infarction on ECG $(n=12)$. The clinical notes of patients so classified, or those admitted with severe chest pain, were then inspected and the WHO criteria for acute myocardial infarction [30], comprising the development of QS waves on the electrocardiogram (Minnesota code 1-1-1 to 1-2-5 or 1-2-7) were applied.

Assay methods. Methods for determining plasma glucose and lipids have been previously reported [31]. Plasminogen activator inhibitor-1 activity was measured using a chromogenic assay (Chromogenix, Stockholm, Sweden) [32]. Fibrinogen was measured using the von Claus assay.

Frozen samples were available on 1947 subjects studied during Phase II. There was an assay loss of $68 \%$ of insulin and $81 \%$ of intact proinsulin after five freeze-thaw cycles, so only continuously frozen samples were assayed. Of the 1947 samples, 1370 had remained continuously frozen during the subsequent $8-12$ years, this sample being random from the whole cohort. Proinsulin and des 31, 32 proinsulin were measured on a single aliquot, while insulin was assayed on separate aliquots in 1116 subjects to avoid the need to assay previously thawed samples. Data were not used because of poor reproducibility of the duplicate samples (coefficient of variation $(\mathrm{CV})>15 \%$ ) or inadequate volume for 182 subjects for intact proinsulin and 232 subjects for des 31,32 proinsulin respectively. Insulin assays were available on all samples, with paired assay CVs of less than $11 \%$, but one sample was excluded because of a mismatch of identification number. The subjects on whom data were available were similar in all characteristics to the total Phase II cohort. Subjects with a history of previously diagnosed diabetes, with a fasting plasma glucose of $7.0 \mathrm{mmol} \cdot \mathrm{l}^{-1}$ or more, or both, were excluded from further analysis ( $n=117$ for insulin, 132 for intact and 128 for des 31, 32 proinsulin). Following these exclusions, 998 insulin results were available and 1056 and 1010 for intact and des 31, 32 proinsulin, respectively, in non-diabetic subjects.

Insulin was assayed in duplicate using a Dako kit (Dako Diagnostics, Ely, Cambs., UK), which shows a less than $1 \%$ crossreactivity with intact and with des 31,32 proinsulin, and has intra-assay and inter-assay coefficients of variation $(\mathrm{CV})$ of $7.5 \%$ and $8.9 \%$, respectively. Assays of proinsulin and des 31 , 32 proinsulin were carried out in duplicate using 2-site monoclonal antibody-based microplate immunoradiometric assays as we have previously described $[17,18,20]$, employing antibodies (Serono Diagnostics, Woking, Surrey, UK) and based on methods previously described [33]. The detection limits for intact and des 31,32 proinsulin were 0.25 and 0.125 pmol. $^{-1}$, respectively. The within-assay and between-assay CVs were $10.1 \%$ and $9.6 \%$ for intact, and $9.3 \%$ and $15.0 \%$ for des 31 , 32 proinsulin. There was no cross-reaction with insulin in either assay. The des 31,32 proinsulin assay showed $59 \%$ crossreactivity with intact proinsulin and the concentration of des 31,32 proinsulin was calculated by subtracting the cross-reactivity of the measured intact proinsulin.

We calculated the sum of proinsulin-like molecules as (intact proinsulin + des 31,32 proinsulin), and the proinsulin ratio as (intact proinsulin + des 31, 32 proinsulin) / insulin.

We analysed the relationships between the sum of proinsulin-like molecules and continuous variables and with CHD in order to permit comparisons with other studies in which the proinsulin assay is not able to measure these molecular species separately. We found no deterioration in any of these molecules in stored samples stored frozen for up to 4 years at $-20^{\circ} \mathrm{C}$. In 40 continuously frozen samples assayed for urea, sodium and cholesterol, results were all within $5 \%$ of original concentrations, excluding sample deterioration. Furthermore, the mean assay concentrations of proinsulin, des 31,32 proinsulin and insulin in this study are similar to those we found in other similar populations $[18,20]$, providing a strong probability of stability in these frozen samples.

Statistical Analyses. The data were analysed using Stata. Linear correlation and regression analyses were done to assess the relationships between the variables, with logarithmic transformation of skewed data, with and without adjustment for age and BMI and other variables. Because some cases of incident CHD defined electrocardiographically could not be dated, we used minimum likelihood logistic regression analysis, and not Cox proportional hazards models, to assess the independent contribution of absolute and relative concentrations of proinsulin-like molecules, and of insulin, in models controlling for age, BMI and other risk factors. We also did multiple regression analyses for combinations of insulin-like molecules, using both actual concentrations and residuals, the latter to overcome the problem of collinearity. In these analyses, concentrations of insulin-like molecules were analysed as continuous variables because no evidence for threshold or other non-linear effects on the relationships between these concentrations and incident CHD was found. To compare risks associated with different variables, risk was expressed as a standardised odds ratio (SOR), representing the change in events corresponding to a one standard deviation change in the variable under consideration. The $95 \%$-CIs are also given. Results are presented for analyses employing all valid subjects but results were very similar when using only the smaller number of subjects with a complete set of data. We estimate that the numbers of subjects studied provide sufficient power to detect correlation coefficients of around 0.07 at a $5 \%$ level of significance. We also estimated that, with around 70 deaths from CHD and around 130 incident cases, the numbers were sufficient to detect an SOR of around 1.3 in CHD incidence and 1.6 in CHD deaths with $80 \%$ power. Data are expressed as mean (standard deviation (SD)) for normally distributed variables and median (interquartile (IQ) range) for skewed variables. A $p$ value of less than 0.5 was considered to be statistically significant.

\section{Results}

The characteristics of the study cohort are shown in Table 1. The relationship of concentrations of insulin, of proinsulin-like molecules and of the derived sum and ratio are shown in Table 2 as partial correlation coefficients adjusted for age and BMI. The simple correlations of insulin, proinsulin and of des 31,32 proinsulin with BMI $(r=0.36-0.45)$, triglyceride $(r=0.25-0.31)$, HDL-cholesterol $(r=-0.17$ to -0.21$)$, systolic $(r=0.05-0.11)$ and diastolic blood pressure $(r=0.11-0.15)$ were similarly close, those with risk factors being somewhat reduced by adjustment for age and BMI (Table 2). Correlations of concentrations of insulin and of proinsulin-like molecules with those of plasminogen activator inhibitor-1 antigen were also similar $(r=0.28-0.29)$ and were also re- 
Table 1. Characteristics of study subjects with available measurements of insulin and of proinsulin-like molecules in Phase II of the Caerphilly study

\begin{tabular}{|c|c|c|}
\hline & & $n$ \\
\hline Age (years) & $57.1(4.5)$ & 1181 \\
\hline Height $(\mathrm{m})$ & $1.71(0.06)$ & 1168 \\
\hline $\mathrm{BMI}\left(\mathrm{kg} \cdot \mathrm{m}^{-2}\right)$ & $26.4(3.6)$ & 1165 \\
\hline Recalled birth weight (ozs) & $128(112,144)$ & 480 \\
\hline $\begin{array}{l}\text { Non-manual/manual social class } \\
(\mathrm{I}-\mathrm{IIINM} / \mathrm{IIIM}-\mathrm{V})(\%)\end{array}$ & $29.8 / 70.2$ & 1179 \\
\hline $\begin{array}{l}\text { Paternal social class(I-IIINM/IIIM-V) } \\
(\%)\end{array}$ & $10.3 / 89.7$ & 861 \\
\hline Systolic blood pressure $(\mathrm{mmHg})$ & $147.1(23.0)$ & 1179 \\
\hline Diastolic blood pressure $(\mathrm{mmHg})$ & $84.5(12.3)$ & 1179 \\
\hline Total cholesterol $\left(\mathrm{mmol} \cdot \mathrm{l}^{-1}\right)$ & $5.56(4.95,6.32)$ & 1177 \\
\hline $\begin{array}{l}\text { Low density lipoprotein cholesterol } \\
\left(\mathrm{mmol} \cdot \mathrm{l}^{-1}\right)\end{array}$ & $3.70(3.14,4.35)$ & 1177 \\
\hline $\begin{array}{l}\text { High density lipoprotein cholesterol } \\
\left(\mathrm{mmol} \cdot \mathrm{l}^{-1}\right)\end{array}$ & $1.00(0.85,1.16)$ & 1177 \\
\hline Triglyceride $\left(\mathrm{mmol} \cdot \mathrm{l}^{-1}\right)$ & $1.60(1.16,2.27)$ & 1177 \\
\hline $\begin{array}{l}\text { Plasminogen activator inhibitor- } 1 \\
\text { (\% pool) }\end{array}$ & $134.1(56.8)$ & 1093 \\
\hline Fibrinogen $\left(\mathrm{mg} \cdot \mathrm{dl}^{-1}\right)$ & $409(88)$ & 1172 \\
\hline Insulin $\left(\mathrm{pmol} \cdot \mathrm{l}^{-1}\right)$ & $26.4(18.4,39.4)$ & 998 \\
\hline Intact proinsulin $\left(\mathrm{pmol} \cdot \mathrm{l}^{-1}\right)$ & $2.6(1.8,3.9)$ & 1056 \\
\hline Des 31,32 proinsulin $\left(\mathrm{pmol} \cdot \mathrm{l}^{-1}\right)$ & $2.5(1.6,4.1)$ & 1010 \\
\hline Sum of insulin-like molecules $\left(\mathrm{pmol} \cdot \mathrm{l}^{-1}\right)$ & $32.7(22.6,46.2)$ & 835 \\
\hline $\begin{array}{l}\text { Sum of proinsulin-like molecules } \\
\left(\mathrm{pmol} \cdot \mathrm{l}^{-1}\right)\end{array}$ & $5.2(3.6,7.8)$ & 1010 \\
\hline Proinsulin ratio & $0.20(0.14,0.30)$ & 835 \\
\hline
\end{tabular}

Data are shown as mean (SD) for normally distributed variables and median (interquartile range) for skewed data duced after adjustment. There were negative relationships between concentrations of proinsulin-like molecules and birth weight, and positive correlations between those of all molecules and fibrinogen, after adjustment for age and BMI. Concentrations of insulin (but not of proinsulin) correlated positively with height but not with social class. The correlations of the derived sum of proinsulin-like molecules paralleled those for the component molecules. The proinsulin-to-insulin ratio related negatively to height, and positively to social class after adjustment for age and BMI. There was no significant relationship between the proinsulin-to-insulin ratio with other risk factors or birth weight. We also found no relationship of proinsulin:insulin ratio with markers of liver or kidney dysfunction (creatinine $r=0.03$, gammaglutamyl transpeptidase $r=0.05)$. Concentrations of insulin-like molecules were moderately intercorrelated, with coefficients of 0.47 and 0.49 for insulin with intact and des 31,32 proinsulin, and of 0.62 for intact with des 31,32 proinsulin.

The independent correlation of proinsulin-like molecules with other variables, after adjusting statistically for the effect of insulin, as well as for age and BMI, were explored using multiple regression models. In these models, concentrations of both intact proinsulin and des 31,32 proinsulin independently correlated with HDL-cholesterol (partial $r=-0.07$ to -0.09 , triglyceride (partial $r=0.11-0.19$ ) and PAI-1 (partial $r=0.12-0.13$ ) once insulin had been entered into the equation with age and BMI. The partial correlation of both insulin and des 31,32 proinsulin with PAI-1 remained significant after further addition of triglyceride to the model $(r=0.08, p=0.03$ and $r=0.09, p=0.01$ respectively). Inclusion of birth weight in these models had little effect on these correlation coefficients (data not shown).

Table 2. Correlation of concentrations of insulin-like molecules, sum of insulin-like molecules and ratio of proinsulin-like molecules to insulin, with anthropometric, haemodynamic and biochemical variables

\begin{tabular}{|c|c|c|c|c|c|}
\hline & Insulin & $\begin{array}{l}\text { Intact } \\
\text { proinsulin }\end{array}$ & $\begin{array}{l}\text { Des } 31,32 \\
\text { proinsulin }\end{array}$ & $\begin{array}{l}\text { Sum of proinsulin } \\
\text { like Molecules }\end{array}$ & $\begin{array}{l}\text { Proinsulin } \\
\text { ratio }\end{array}$ \\
\hline Age (years) & 0.06 & 0.01 & -0.00 & -0.00 & -0.05 \\
\hline $\mathrm{BMI}\left(\mathrm{kg} \cdot \mathrm{m}^{-2}\right)$ & $0.46^{\mathrm{c}}$ & $0.37^{\mathrm{c}}$ & $0.41^{\mathrm{c}}$ & $0.44^{\mathrm{c}}$ & -0.04 \\
\hline Height (metres) & $0.12^{\mathrm{c}}$ & 0.00 & -0.01 & 0.00 & $-0.08^{\mathrm{a}}$ \\
\hline Recalled birth Weight (ozs) & -0.04 & $-0.11^{\mathrm{a}}$ & $-0.12^{\mathrm{a}}$ & $-0.13^{\mathrm{b}}$ & -0.06 \\
\hline Social class & -0.05 & -0.02 & 0.02 & 0.01 & $0.10^{\mathrm{b}}$ \\
\hline Systolic blood pressure $(\mathrm{mmHg})$ & -0.03 & -0.02 & 0.03 & 0.02 & 0.06 \\
\hline Diastolic blood pressure $(\mathrm{mmHg})$ & 0.02 & 0.02 & 0.05 & 0.04 & 0.03 \\
\hline Total cholesterol $\left(\mathrm{mmol} \cdot \mathrm{l}^{-1}\right)$ & $0.08^{\mathrm{a}}$ & $0.09^{\mathrm{b}}$ & $0.07^{\mathrm{b}}$ & $0.10^{\mathrm{b}}$ & \\
\hline Low density lipoprotein cholesterol $\left(\mathrm{mmol} \cdot \mathrm{l}^{-1}\right)$ & 0.02 & 0.04 & -0.01 & 0.02 & -0.01 \\
\hline High density lipoprotein cholesterol $\left(\mathrm{mmol} \cdot \mathrm{l}^{-1}\right)$ & $-0.14^{\mathrm{c}}$ & $0.13^{\mathrm{c}}$ & $-0.14^{\mathrm{c}}$ & $-0.17^{\mathrm{c}}$ & -0.01 \\
\hline Triglyceride $\left(\mathrm{mmol} \cdot \mathrm{l}^{-1}\right)$ & $0.22^{\mathrm{c}}$ & $0.19^{\mathrm{c}}$ & $0.24^{\mathrm{c}}$ & $0.27^{\mathrm{c}}$ & 0.05 \\
\hline Plasminogen activator inhibitor-1 (\% pool) & $0.14^{\mathrm{c}}$ & $0.17^{\mathrm{c}}$ & $0.17^{\mathrm{c}}$ & $0.20^{\mathrm{c}}$ & 0.06 \\
\hline Fibrinogen $\left(\mathrm{mg} \cdot \mathrm{dl}^{-1}\right)$ & $0.07^{\mathrm{a}}$ & $0.06^{\mathrm{a}}$ & $0.12^{\mathrm{c}}$ & $0.12^{\mathrm{c}}$ & 0.04 \\
\hline
\end{tabular}

transformation of skewed data 
Table 3. Logistic regression analyses for incident coronary heart disease (fatal and non-fatal - 127 cases) according to concentrations of insulin-like molecules

\begin{tabular}{|c|c|c|c|c|}
\hline & $n$ & Odds ratio & $95 \%$-CI & $p$ value \\
\hline $\begin{array}{l}\text { Model } 1 \\
\text { Insulin }\end{array}$ & 983 & 1.30 & $0.91,1.85$ & 0.15 \\
\hline $\begin{array}{l}\text { Model } 2 \\
\text { Intact proinsulin }\end{array}$ & 1041 & 1.19 & $0.85,1.67$ & 0.32 \\
\hline $\begin{array}{l}\text { Model } 3 \\
\text { Des } 31,32 \text { proinsulin }\end{array}$ & 997 & 1.38 & $1.02,1.85$ & 0.034 \\
\hline $\begin{array}{l}\text { Model } 4 \\
\text { Sum of proinsulin-like molecules }\end{array}$ & 997 & 1.54 & $1.07,2.20$ & 0.019 \\
\hline $\begin{array}{l}\text { Model } 5 \\
\text { Proinsulin ratio }\end{array}$ & 823 & 1.24 & $0.87,1.77$ & 0.23 \\
\hline $\begin{array}{l}\text { Model } 6 \\
\text { Insulin } \\
\text { Des 31, } 32 \text { proinsulin }\end{array}$ & $\begin{array}{l}823 \\
1.41\end{array}$ & $\begin{array}{l}0.93 \\
1.00,1.99\end{array}$ & $\begin{array}{l}0.62,1.39 \\
0.05\end{array}$ & 0.72 \\
\hline $\begin{array}{l}\text { Model } 7 \\
\text { Insulin } \\
\text { Sum of proinsulin-like molecules }\end{array}$ & $\begin{array}{l}823 \\
1.47\end{array}$ & $\begin{array}{l}0.92 \\
0.95,2.26\end{array}$ & $\begin{array}{l}0.61,1.40 \\
0.08\end{array}$ & 0.71 \\
\hline
\end{tabular}

Data are shown as an odds ratio for each standard deviation change in the dependent variable, while controlling for age and BMI

The results of the logistic regression models are shown in Table 3. In separate models, adjusting for age and BMI, the SOR for des 31, 32 proinsulin $(1.38,95 \%$ CI $1.02-1.85)$ and for the sum of proinsulin-like molecules $(1.54,95 \%$ CI 1.07-2.20) in predicting incident CHD over 10-14 years (113 cases) were somewhat stronger than that for insulin (1.30, $95 \%$ CI 0.91-1.85), despite the fact that these precursor molecules comprise only some $10 \%$ of the total sum. However, in a combined model incorporating insulin and des 31,32 proinsulin, des 31, 32 proinsulin replaced insulin in the prediction of incident CHD (model 6). Similarly, the sum of concentrations of proinsulin-like molecules was stronger than that of insulin in a combined model (model 7) but did not reach conventional levels of significance. Similar conclusions were found when using residuals of proinsulin-like molecules, related to concentrations of insulin, in joint models. The results of logistic regression analyses for both fatal CHD (63 cases) and non-fatal CHD (64 cases), were similar to those for all incident $\mathrm{CHD}$, but, because of smaller numbers, less consistent patterns of association were seen (data not shown). We also compared the estimates with hazards ratios derived from Cox proportional hazards models in those subjects with clinical events (excluding cases diagnosed by ECG). These estimates were closely similar, suggesting that concentrations of insulin-like molecules do not disproportionately influence early or late events. The results of all these analyses were hardly affected by excluding adjustment for BMI.

We studied the effect of adding other risk factors to such logistic regression models (Table 4). With incidence of $\mathrm{CHD}$ as the dependent variable, the SORs for insulin, for des 31,32 proinsulin and for sum of proinsulin-like molecules were hardly affected by adding standard risk factors to age and BMI in the models. Further adjustment for triglyceride and HDL-cholesterol reduced the SORs by around one third, the SORs for proinsulin-like molecules no longer remaining significant at the $5 \%$ level in this model. Virtually identical results were obtained by adding the total-to-HDL-cholesterol ratio in these adjustments instead of adjusting for LDL-cholesterol in model 2 followed by HDL-cholesterol in model 3. Additional adjustment for PAI-1 further reduced the SORs by around half. Similar effects of adjusting for risk factors were found in combined models incorporating both insulin and proinsulin-like models. Inclusion of fasting glucose concentration in these models was without significant effect on the relationship between insulin-like molecules and incident CHD (data not shown). There was no statistical evidence of a significant interaction between concentrations of insulin-like molecules and patterns of dyslipidaemia or obesity in predicting incident CHD. Once again, including birth weight in these models had little effect on the SORs, although smaller numbers of subjects resulted in a reduction in the degrees of significance. In this cohort there was no significant difference in recalled birth weight between those with and without incident CHD.

\section{Discussion}

In a study of 1181 middle-aged, non-diabetic men followed up over a period of some 10-14 years, we found significant relationships between incident CHD and absolute concentrations of proinsulin-like molecules. There were also significant relationships 
Table 4. Multivariate logistic regression analyses for incident coronary heart disease (127 cases) according to concentrations of insulin-like molecules and risk factors

\begin{tabular}{|c|c|c|c|c|}
\hline 1. Insulin with risk factors & $n$ & Odds ratio & $95 \%-\mathrm{CI}$ & $p$ value \\
\hline $\begin{array}{l}\text { Model } 1 \\
\text { Insulin } \\
\text { Model } 2\end{array}$ & 983 & 1.30 & $0.91,1.85$ & 0.15 \\
\hline $\begin{array}{l}\text { Insulin adjusted for standard risk factors(smoking, diastolic blood pressure, } \\
\text { LDL-cholesterol) } \\
\text { Model } 3\end{array}$ & 978 & 1.28 & $0.88,1.82$ & 0.20 \\
\hline $\begin{array}{l}\text { Insulin adjusted for standard risk factors, triglyceride and HDL-cholesterol } \\
\text { Model } 4\end{array}$ & 978 & 1.09 & $0.76,1.58$ & 0.63 \\
\hline $\begin{array}{l}\text { Insulin adjusted for standard risk factors, triglyceride, HDL- cholesterol } \\
\text { and PAI-1 } \\
\text { Model } 5\end{array}$ & 911 & 1.15 & $0.77,1.73$ & 0.50 \\
\hline $\begin{array}{l}\text { Insulin adjusted for standard risk factors, triglyceride, HDL-cholesterol, } \\
\text { PAI-1 and birth weight }\end{array}$ & 353 & 1.10 & $0.55,2.18$ & 0.78 \\
\hline 2. Des 31,32 proinsulin with risk factors & $n$ & Odds ratio & $95 \%-C I$ & $p$ value \\
\hline $\begin{array}{l}\text { Model } 1 \\
\text { Des } 31,32 \text { proinsulin } \\
\text { Model } 2\end{array}$ & 997 & 1.38 & $1.02,1.85$ & 0.034 \\
\hline $\begin{array}{l}\text { Des } 31,32 \text { proinsulin adjusted for standard risk factors (smoking, diastolic blood } \\
\text { pressure, LDL-cholesterol) } \\
\text { Model } 3\end{array}$ & 992 & 1.35 & $1.00,1.82$ & 0.048 \\
\hline $\begin{array}{l}\text { Des } 31,32 \text { proinsulin adjusted for standard risk factors, triglyceride and } \\
\text { HDL-cholesterol } \\
\text { Model } 4\end{array}$ & 992 & 1.26 & $0.92,1.71$ & 0.15 \\
\hline $\begin{array}{l}\text { Model } 4 \\
\text { Des } 31,32 \text { proinsulin adjusted for standard risk factors, triglyceride, } \\
\text { HDL-cholesterol and PAI-1 } \\
\text { Model } 5\end{array}$ & 919 & 1.17 & $0.85,1.61$ & 0.35 \\
\hline $\begin{array}{l}\text { Des } 31,32 \text { proinsulin adjusted for standard risk factors, triglyceride, } \\
\text { HDL-cholesterol, PAI-1 and birth weight }\end{array}$ & 375 & 1.30 & $0.77,2.18$ & 0.32 \\
\hline 3. Sum of proinsulin-like molecules with risk factors & $n$ & Odds ratio & $95 \%-\mathrm{CI}$ & $p$ value \\
\hline $\begin{array}{l}\text { Model } 1 \\
\text { Sum of proinsulin-like molecules } \\
\text { Model } 2\end{array}$ & 997 & 1.54 & $1.07,2.20$ & 0.019 \\
\hline $\begin{array}{l}\text { Sum of proinsulin-like molecules adjusted for standard risk factors } \\
\text { (smoking, diastolic blood pressure, LDL-cholesterol) } \\
\text { Model } 3\end{array}$ & 992 & 1.47 & $1.02,2.12$ & 0.036 \\
\hline $\begin{array}{l}\text { Sum of proinsulin-like molecules adjusted for standard risk factors, } \\
\text { triglyceride and HDL-cholesterol } \\
\text { Model } 4\end{array}$ & 992 & 1.34 & $0.92,1.96$ & 0.13 \\
\hline $\begin{array}{l}\text { Sum of proinsulin-like molecules adjusted for standard risk factors, } \\
\text { triglyceride, HDL-cholesterol and PAI-1 } \\
\text { Model } 5\end{array}$ & 919 & 1.21 & $0.81,1.81$ & 0.36 \\
\hline $\begin{array}{l}\text { Sum of proinsulin-like molecules adjusted for standard risk factors, } \\
\text { triglyceride, HDL-cholesterol, PAI-1 and birth weight }\end{array}$ & 375 & 1.26 & $0.66,2.41$ & 0.48 \\
\hline 4. Insulin plus des 31,32 proinsulin with risk factors & $n$ & Odds ratio & $95 \%-\mathrm{CI}$ & $p$ value \\
\hline $\begin{array}{l}\text { Model } 1 \\
\text { Insulin } \\
\text { Des } 31,32 \text { proinsulin } \\
\text { Model } 2\end{array}$ & $\begin{array}{l}823 \\
1.41\end{array}$ & $\begin{array}{l}0.93 \\
1.00,1.99\end{array}$ & $\begin{array}{l}0.62,1.39 \\
0.05\end{array}$ & 0.72 \\
\hline $\begin{array}{l}\text { Insulin } \\
\text { Des } 31,32 \text { proinsulin adjusted for standard risk factors (smoking, diastolic }\end{array}$ & 819 & 0.91 & $0.60,1.37$ & 0.64 \\
\hline $\begin{array}{l}\text { blood pressure, LDL-cholesterol) } \\
\text { Model } 3\end{array}$ & 1.41 & $0.99,1.99$ & 0.05 & \\
\hline $\begin{array}{l}\text { Insulin } \\
\text { Des } 31,32 \text { proinsulin adjusted for standard risk factors, triglyceride and }\end{array}$ & 819 & 0.85 & $0.56,1.28$ & 0.43 \\
\hline $\begin{array}{l}\text { HDL-cholesterol } \\
\text { Model } 4\end{array}$ & 1.31 & $0.92,1.87$ & 0.13 & \\
\hline Insulin & 766 & 0.92 & $0.58,1.46$ & 0.72 \\
\hline $\begin{array}{l}\text { Des } 31,32 \text { proinsulin adjusted for standard risk factors, triglyceride, } \\
\text { HDL-cholesterol and PAI-1 }\end{array}$ & 1.19 & $0.82,1.72$ & 0.35 & \\
\hline
\end{tabular}


Table 4. (continued)

\begin{tabular}{|c|c|c|c|c|}
\hline & $n$ & Odds ratio & $95 \%-\mathrm{CI}$ & $p$ value \\
\hline $\begin{array}{l}\text { Model } 5 \\
\text { Insulin } \\
\text { Des } 31,32 \text { proinsulin adjusted for standard risk factors, triglyceride, } \\
\text { HDL-cholesterol, PAI-1 and birth weight }\end{array}$ & 1.76 & 0.89 & $\begin{array}{l}0.41,1.90 \\
0.09\end{array}$ & 0.77 \\
\hline 5. Insulin plus sum of proinsulin-like molecules with risk factors & $n$ & Odds ratio & $95 \%-\mathrm{CI}$ & $p$ value \\
\hline $\begin{array}{l}\text { Model } 1 \\
\text { Insulin } \\
\text { Sum of proinsulin-like molecules } \\
\text { Model } 2\end{array}$ & $\begin{array}{l}823 \\
1.47\end{array}$ & $\begin{array}{l}0.92 \\
0.95,2.26\end{array}$ & $\begin{array}{l}0.61,1.40 \\
0.08\end{array}$ & 0.71 \\
\hline Insulin & 819 & 0.91 & $0.60,1.39$ & 0.67 \\
\hline $\begin{array}{l}\text { Sum of proinsulin-like molecules adjusted for standard risk factors (smoking, } \\
\text { diastolic blood pressure, LDL-cholesterol) } \\
\text { Model } 3\end{array}$ & 1.43 & $0.93,2.21$ & 0.11 & \\
\hline Insulin & 819 & 0.86 & $0.56,1.30$ & 0.47 \\
\hline $\begin{array}{l}\text { Sum of proinsulin-like molecules adjusted for standard risk factors, triglyceride } \\
\text { and HDL-cholesterol } \\
\text { Model } 4\end{array}$ & 1.30 & $0.83,2.03$ & 0.24 & \\
\hline Insulin & 766 & 0.94 & $0.59,1.52$ & 0.81 \\
\hline $\begin{array}{l}\text { Sum of proinsulin-like molecules adjusted for standard risk factors, } \\
\text { triglyceride, HDL-cholesterol and PAI-1 } \\
\text { Model } 5\end{array}$ & 1.13 & $0.70,1.82$ & 0.61 & \\
\hline Insulin & 305 & 0.97 & $0.44,2.13$ & 0.94 \\
\hline $\begin{array}{l}\text { Sum of proinsulin-like molecules adjusted for standard risk factors, triglyceride, } \\
\text { HDL-cholesterol, PAI-1 and birth weight }\end{array}$ & 1.44 & $0.66,3.14$ & 0.36 & \\
\hline
\end{tabular}

Data are shown as an odds ratio for each standard deviation change in the dependent variable. In all cases age and body mass index were controlled for LDL (low density lipoprotein), HDL (high density lipoprotein), PAI-1 (plasminogen activator inhibitor-1)

between concentrations of these molecules, but not of proinsulin-to-insulin ratio, and several components of the insulin resistance syndrome, as well as fibrinogen. In contrast to our previous study [18] we found no consistent relationship between concentrations of insulin-like molecules and those of LDL-cholesterol. The relationships with risk factors cannot simply be explained by the increase in concentrations of all three molecules found with obesity and with insulin resistance $[34,35]$ in non-diabetic subjects, because in multiple regression models, the relationships between levels of risk factors and concentrations of the proinsulin-like molecules remains significant once BMI and insulin are included in the equation. Equally difficult to explain is the finding that absolute concentrations of proinsulin-like molecules predict incident CHD over a prolonged period of follow up.

Previous studies have shown that absolute concentrations of proinsulin are higher, together with insulin, in obese and insulin-resistant subjects [13, 15, 34-38]. More contentious is whether proinsulin-to-insulin ratios are higher in insulin-resistant subjects, as well as being associated with reduced beta-cell function [34, $35,37,39]$. Studies have related relative proinsulin concentrations to measures of insulin sensitivity and suggested that insulin-resistant subjects have normal or lower proinsulin-to-insulin ratios [34, 36, 37], and other studies have shown no increase in this ratio in obesity [38] or in highly insulin-resistant cohorts [13].
However, one study in an ethnically mixed cohort of 423 men and women, suggested an increase in the proinsulin-to-insulin ratio in individuals with metabolic disorders of the insulin resistance syndrome [40] implying a relationship not with insulin resistance in itself but with its associated cardiovascular risk factors. In the current study, which was over twice as large and in a homogeneous cohort of men, we found no such relationships between risk factors and the proinsulin-to insulin ratio. In a recent analysis, absolute concentrations of proinsulin-like molecules correlated significantly with concentrations of PAI-1 in subjects with varying degrees of glucose intolerance, even after controlling for insulin sensitivity as measured by an intravenous glucose tolerance test [41].

Proinsulin and des 31,32 proinsulin bind to the insulin receptor with a much lower affinity than insulin, and have a much weaker biological effect when administered $[14,42]$. We tested the hypothesis that concentrations of proinsulin-like molecules could play a role in determining risk, at least in patients with Type II (non-insulin-dependent) diabetes mellitus where the absolute and relative concentrations are much higher. In two separate studies, we treated such patients with either exogenous insulin or sulphonylureas to assess the effects of suppressing or stimulating, respectively, in concentrations of proinsulinlike molecules without affecting glycaemic control $[43,44]$. In neither study was a change in concentrations of proinsulin-like molecules associated with an 
effect on lipids or blood pressure, although reducing proinsulin concentrations with insulin produced a reduction in PAI-1 activity. This observation, as well as the strength of the relationships of proinsulin-like molecules and risk factors in this and our previous studies $[18,20]$ indicates that the relationship between proinsulin concentrations and those of risk factors is probably not one of cause and effect but could point to the existence of a common antecedent.

In a cross-sectional study in non-diabetic subjects, we found similar relationships between absolute concentrations of proinsulin-like molecules and prevalent CHD as for insulin [20], again arguing against a causative role for proinsulin in CHD. We also explored the predictive power of proinsulin-like molecules for incident CHD in a small study, with consequent problems of type 2 error [20]. Cross-sectional studies explored the relationship between proinsulin concentrations and prevalence of CHD. One study found increased absolute, but not relative, concentrations of proinsulin in patients with angiographically defined $\mathrm{CHD}$, an association which disappeared after adjustment for BMI [45]. Another study in Japanese American men found no increase in proinsulin concentrations in subjects with clinically and electrocardiographically defined CHD [46]. Finally, a Swedish study explored the relationship between concentrations of insulin-like molecules and the extent of coronary atherosclerosis in 62 non-diabetic men with myocardial infarction under 65 years of age [47]. The investigators demonstrated a statistically independent effect of fasting proinsulin concentrations on the extent of atheroma, with the influence of insulin replaced in the model.

We have found a significant, and seemingly independent, relationship between absolute concentrations of proinsulin-like molecules and incident CHD. We have shown that, despite their presence in very low concentrations, concentrations of proinsulin-like molecules replace insulin in the model as predictors of incident CHD. These observations, which support those of a recently-published Swedish case-control study [48], suggest that the relationship between proinsulin concentration and CHD, is probably not simply a common consequence of insulin resistance. In epidemiological studies insulin, concentrations are generally accepted to provide the best marker of insulin resistance [49], although the longer half-life of proinsulin-like molecules could reduce the intra-individual variance of concentrations of these molecules compared with insulin. In analyses exploring the potential dependence of these findings on the cluster of metabolic, fibrinolytic and haemodynamic abnormalities which are associated with hyperinsulinaemia and with higher concentrations of proinsulin, the significance of the concentration of proinsulin-like molecules was weakened by inclusion of triglyceride and PAI-1 concentrations in the models. A report from this cohort suggested that around half of the predic- tive effect of insulin for CHD could be explained on the basis of confounding by triglyceride concentration [10]. We explored the possibility that intrauterine growth retardation represents the common antecedent, and found inverse relationships with concentrations of proinsulin-like molecules. Bearing in mind that birth weight was recalled and not recorded, that preterm births were not excluded [22], and that birth weight might not adequately reflect intrauterine growth retardation [50], we did not, however, find any evidence that birth weight was a confounder in the relationship between concentrations of insulin-like molecules and incident CHD in this study. The lack of relationship between proinsulin-to-insulin ratio and markers of hepatic or renal disease excludes the possibility of differential reductions in clearance of the molecules in such conditions. We must postulate one of two possibilities: firstly, that higher concentrations of proinsulin-like molecules reflect another, unmeasured cause antecedent, such as concentrations of proinflammatory cytokines [51]. Or, secondly, through actions on a putative proinsulin receptor [52] or through other biological actions that are not yet known, proinsulin-like molecules could themselves play some role in causing atherothrombosis.

The second hypothesis that these risk markers are causative in the pathway of CHD needs data from intervention studies in which concentrations of proinsulin-like molecules are reduced. It might be postulated that the recent observations of the UK Prospective Diabetes Study (UKPDS) [53] fail to provide support. We have previously shown that treatment of Type II diabetic subjects with insulin reduces concentrations of proinsulin-like molecules to a greater degree than with treatment using sulphonylureas to achieve similar degrees of glycaemia [43, 44]. The observations that treatment with insulin and with sulphonylureas in the UKPDS provided similar benefit in terms of CHD risk reduction [53] might argue against a role for proinsulin-like molecules in cardiovascular risk, at least in Type II diabetes.

In conclusion, we have shown a similar relationship between concentrations of proinsulin-like molecules and several cardiovascular risk factors as have been previously observed for insulin. We also found that absolute concentrations of these molecules predict incident CHD in middle-aged men, and, furthermore, replace insulin as a predictor of CHD in statistical models including both molecular species. The mechanisms of these associations is still to be explored.

Acknowledgements. This work was funded through a Medical Research Council Project Grant (G9504631). Additional aspects of this study were supported by Group Support from the British Diabetic Association, Diabetes and Related Diseases Research, the Joan Oliver Bequest and S. Hammerson. We are grateful to J. Thornton for the assays of insulin and proinsulin-like molecules. 


\section{References}

1. DeFronzo RA (1981) The effect of insulin on renal sodium metabolism. A review with clinical implications. Diabetologia 21: 165-171

2. Landsberg L (1989) Diet, obesity and hypertension; an hypothesis involving insulin, the sympathetic nervous system, and adaptive thermogenesis. Q J Med 236: 1081-1090

3. Golay A, Chen Y-DI, Reaven GM (1986) Effect of differences in glucose tolerance on insulin's ability to regulate carbohydrate and free fatty acid metabolism in obese individuals. J Clin Endocrinol Metab 62: 1081-1088

4. Reaven GM (1988) Role of insulin resistance in human disease. Diabetes 37: 1595-1607

5. Stout RW (1990) Insulin and atheroma. 20 year perspective. Diabetes Care 13: 631-655

6. Pyörälä K (1979) Relationship of glucose tolerance and plasma insulin to the incidence of coronary heart disease: results from two population studies in Finland. Diabetes Care 2: 131-141

7. Ducimetière P, Eschwège E, Papoz L, Richard J-L, Claude CR, Rosselin G (1980) Relationship of plasma insulin levels to the incidence of myocardial infarction and coronary heart disease mortality in a middle-aged population. Diabetologia 19: 205-210

8. Welborn TA, Wearne K (1979) Coronary heart disease incidence and cardiovascular mortality in Busselton with reference to glucose and insulin concentrations. Diabetes Care 2: $154-160$

9. Després J-P, Lamarche B, Mauriège P et al. (1996) Hyperinsulinemia as an independent risk factor for ischemic heart disease. N Engl J Med 334: 952-957

10. Yarnell JWG, Sweetnam PM, Marks V et al. (1994) Insulin in ischaemic heart disease: are associations mediated by triglyceride levels? The Caerphilly prospective study. Br Heart J 71: 293-296

11. Ruige JB, Assendelft WJ, Dekker JM, Kostense PJ, Heine RJ, Bouter LM (1998) Insulin and risk of cardiovascular disease: a meta-analysis. Circulation 97: 996-1001

12. Temple RC, Clark P, Schneider A et al. (1990) Radioimmunoassay may overestimate insulin in non-insulin-dependent diabetics. Clin Endocrinol (Oxf) 32: 689-693

13. Nagi DK, Knowler WC, Mohamed-Ali V, Bennett PH, Yudkin JS (1998) Intact proinsulin, des 31, 32 proinsulin, and specific insulin concentrations among nondiabetic and diabetic subjects in populations at varying risk of type 2 diabetes. Diabetes Care 21: 127-133

14. Yudkin JS (1993) Circulating proinsulin-like molecules. J Diabetes Complications 7: 113-123

15. Saad MF, Kahn SE, Nelson RG et al. (1990) Disproportionately elevated proinsulin in Pima Indians with noninsulin-dependent diabetes. J Clin Endocrinol Metab 70: 1247-1253

16. Temple RC, Carrington CA, Luzio SD et al. (1989) Insulin deficiency in non-insulin-dependent diabetes. Lancet i: 293-295

17. Nagi DK, Hendra TJ, Ryle AJ et al. (1990) The relationship of concentrations of insulin, intact proinsulin and 32-33 split proinsulin with cardiovascular risk factors in Type II (non-insulin dependent) diabetic subjects. Diabetologia 33: 532-537

18. Mohamed-Ali V, Gould MM, Gillies S, Goubet S, Yudkin JS, Haines AP (1995) Association of proinsulin-like molecules with lipids and fibrinogen in non-diabetic subjects evidence against a modulating role for insulin. Diabetologia 38: 1110-1116
19. Haffner SM, Mykkänen L, Stern MP, Valdez RA, Heisserman JA, Bowsher RR (1993) Relationship of proinsulin and insulin to cardiovascular risk factors in non-diabetic subjects. Diabetes 42: 1297-1302

20. Yudkin JS, Denver AE, Mohamed-Ali V et al. (1997) The relationship of concentrations of insulin and proinsulinlike molecules with coronary heart disease prevalence and incidence. A study of two ethnic groups. Diabetes Care 20: 1093-1100

21. Phillips DIW, Barker DJP, Hales CN, Hirst S, Osmond C (1994) Thinness at birth and insulin resistance in adult life. Diabetologia 37: 150-154

22. McKeigue PM, Lithell HO, Leon DA (1998) Glucose tolerance and resistance to insulin-stimulated glucose uptake in men aged 70 years in relation to size at birth. Diabetologia 41: $1133-1138$

23. Barker DJP, Hales CN, Fall CHD, Osmond C, Phipps K, Clark PMS (1993) Type II (non-insulin-dependent) diabetes mellitus, hypertension and hyperlipidaemia (syndrome $\mathrm{X})$ : relation to reduced fetal growth. Diabetologia 36: 62-67

24. Byberg L, McKeigue PM, Zethelius B, Lithell HO (2000) Birth weight and the insulin resistance syndrome: association of low birth weight with truncal obesity and raised plasminogen activator inhibitor-1 but not with abdominal obesity or plasma lipid disturbances. Diabetologia 43: $54-60$

25. Williams DRR, Byrne C, Clark PMS et al. (1991) Raised proinsulin as an early indicator of $\beta$-cell dysfunction. BMJ 303: 95-96

26. Yarnell JWG, Baker IA, Sweetnam PM et al. (1991) Fibrinogen, viscosity and white blood cell count are major risk factors for ischemic heart disease. Circulation 83: 837-844

27. Rose GA, Blackburn H (1968) Cardiovascular survey methods. WHO Monograph Series No 56, World Health Organisation, Geneva

28. Frankel S, Elwood P, Sweetnam P, Yarnell J, Davey Smith G (1996) Birthweight, adult risk factors and incident coronary heart disease: the Caerphilly study. Public Health 110: 139-143

29. Frankel S, Elwood P, Sweetnam P, Yarnell J, Davey Smith G (1996) Birthweight, body-mass index in middle age, and incident coronary heart disease. Lancet 348: 1478-1480

30. WHO Regional Office for Europe (1976) Public Health in Europe, 5. Myocardial Infarction Community Registers. World Health Organisation, Copenhagen, Annexe I

31. Yarnell JWG, Pickering JE, Elwood PC et al. (1994) Does non-diabetic hyperglycaemia predict future IHD? Evidence from the Caerphilly and Speedwell Studies. J Clin Epidemiol 47: 383-388

32. Lowe GDO, Yarnell JWG, Sweetnam PM, Rumley A, Thomas HF, Elwood PC (1998) Fibrin D-dimer, tissue plasminogen activator, plasminogen activator inhibitor, and the risk of major ischaemic heart disease in the Caerphilly Study. Thromb Haemost 79: 129-133

33. Sobey WJ, Beer SF, Carrington CA et al. (1989) Sensitive and specific two-site immunoradiometric assays for human insulin, proinsulin, 65-66 split and 32-33 split proinsulin. Biochem J 260: 535-541

34. Phillips DI, Clark PM, Hales CN, Osmond C Understanding oral glucose tolerance: comparison of glucose or insulin measurements during the oral glucose tolerance test with specific measurements of insulin resistance and insulin secretion. Diabet Med 11: 286-292

35. Mykkänen L, Zaccaro DJ, Hales CN, Festa A, Haffner SM (1999) The relation of proinsulin and insulin to insulin sen- 
sitivity and acute insulin response in subjects with newly-diagnosed Type II diabetes: the Insulin Resistance Atherosclerosis Study. Diabetologia 42: 1060-1066

36.Wang P-W, Abbasi F, Carantoni M, Chen YI, Azhar S, Reaven GM Insulin resistance does not change the ratio of proinsulin to insulin in normal volunteers. J Clin Endocrinol Metab 82: 3221-3224

37. Mykkänen L, Haffner SM, Hales CN, Rönnemaa T, Laakso M (1997) The relation of proinsulin, insulin, and proinsulin-to-insulin ratio to insulin sensitivity and acute insulin response in normoglycemic subjects. Diabetes 46: 1990-1995

38. Proudler AJ, Godsland IF, Stevenson JC. (1994) Insulin propeptides in conditions associated with insulin resistanc in humans and their relevance to insulin measurements. Metabolism 43: 446-449

39. Røder ME, Porte D, Schwartz RS, Kahn SE (1998) Disproportionately elevated proinsulin levels reflect the degree of impaired B cell secretory capacity in patients with noninsulin-dependent diabetes. J Clin Endocrinol Metab 83: 604-608

40. Haffner SM, Mykkänen L, Valdez RA et al. (1994) Disproportionately increased proinsulin levels are associated with the insulin resistance syndrome. J Clin Endocrinol Metab 79: $1806-1810$

41. Festa A, D'Agostino R Jr, Mykkänen L et al. (1999) Relative contribution of insulin and its precursors to fibrinogen and PAI-1 in a large population with different states of glucose tolerance. The Insulin Resistance Atherosclerosis Study (IRAS). Arterioscler Thromb Vasc Biol 19: 562-568

42. Glauber HS, Henry R, Wallace P et al. (1987) The effects of biosynthetic human proinsulin on carbohydrate metabolism in non-insulin-dependent diabetes mellitus. N Engl $\mathbf{J}$ Med 316: 443-449

43. Jain SK, Nagi DK, Slavin BM, Lumb PJ, Yudkin JS (1993) Insulin therapy in type 2 diabetic subjects suppresses plasminogen activator inhibitor (PAI-1) activity and proinsulin-like molecules independently of glycaemic control. Diabet Med 10: 27-32

44. Panahloo A, Mohamed-Ali V, Andrés C, Denver AE, Yudkin JS (1998) Effect of insulin versus sulfonylurea therapy on cardiovascular risk factors and fibrinolysis in type II diabetes. Metabolism 47: 637-643

45. Katz RJ, Ratner RE, Cohen RM, Eisenhower E, Verme D (1996) Are insulin and proinsulin independent risk markers for premature coronary artery disease? Diabetes 45: 736-741

46. Kahn SE, Leonetti DL, Prigeon RL, Boyko EJ, Bergstrom RW, Fujimoto WY (1995) Relationship of proinsulin and insulin with non-insulin dependent diabetes mellitus and coronary heart disease in Japanese-American men: impact of obesity - clinical research centre study. J Clin Endocrinol Metab 80: 1399-1406

47. Båvenholm P, Proudler A, Tornvall P et al. (1995) Insulin, intact and split proinsulin, and coronary artery disease in young men. Circulation 92: 1422-1429

48. Lindahl B, Dinesen B, Eliasson M et al. (1999) High proinsulin concentration precedes acute myocardial infarction in a nondiabetic population. Metabolism 48: 1197-1202

49. Laakso M (1993) How good a marker is insulin level for insulin resistance? Am J Epidemiol 137: 959-165

50. Andersson SW, Niklasson A, Lapidus L, Hallberg L, Bengtsson C, Hulthén L (2000) Poor agreement between self-reported birth weight and birth weight from original records in adult women. Am J Epidemiol 152: 609-616

51. Hales CN, Barker DJP, Martyn CN (1992) Type II (non-insulin-dependent) diabetes mellitus: the thrifty phenotype hypothesis. Diabetologia 46: 595-601

52. Yudkin JS, Stehouwer CDA, Emeis JJ, Coppack SW (1999) C-reactive protein in healthy subjects: association with obesity, insulin resistance, and endothelial dysfunction. a potential role for cytokines originating from adipose tissue? Arterioscleros Thromb Vasc Biol 19: 972-978

53. Jehle PM, Lutz MP, Fussgaenger RD (1996) High affinity binding sites for proinsulin in human IM-9 lymphoblasts. Diabetologia 39: 421-432

54. UK Prospective Diabetes Study (UKPDS) Group (1998) Intensive blood-glucose control with sulphonylureas or insulin compared with conventional treatment and risk of complications in patients with type 2 diabetes (UKPDS 33). Lancet 352: 837-853 